\title{
Role of Village Head's Leadership in Increasing Work Satisfaction of Apparatus of Mokupo Village, Karamat District, Buol Regency
}

\author{
Sri Yanti U.M. Armin 8 (D) \\ Study Program of State Administration, Stisipol Mujahidin Buol, Indonesia
}

× Corresponding Author: Sri Yanti U.M. Armin, E-mail: sriyantiumarmin@gmail.com

\begin{tabular}{|c|c|}
\hline ARTICLE INFORMATION & ABSTRACT \\
\hline $\begin{array}{l}\text { Received: August 23, } 2021 \\
\text { Accepted: September 22, } 2021 \\
\text { Volume: } 3 \\
\text { Issue: } 9 \\
\text { DoI: } 10.32996 / \text { jhsss.2021.3.9.5 }\end{array}$ & $\begin{array}{l}\text { In a village government, the need to carry out social functions internally and } \\
\text { externally can significantly affect the survival of the village. Therefore, the principle of } \\
\text { leadership is of paramount importance for the achievement of a village's objectives. In } \\
\text { this regard, leadership is influential to several aspects of an organization, including } \\
\text { the members' work performance and work satisfaction. Thus, the achievement of work } \\
\text { satisfaction is a crucial objective to generate optimum performance and contribute to }\end{array}$ \\
\hline $\begin{array}{l}\text { Leadership, Work Satisfaction, } \\
\text { Village Head, Apparatus }\end{array}$ & $\begin{array}{l}\text { community development. Employing a qualitative method, the study found that the } \\
\text { role of a village head is very influential in directing, guiding, and encouraging the } \\
\text { village apparatus in carrying out their duties and contributing to the village } \\
\text { development. Moreover, the village head's leadership has contributed to the } \\
\text { achievement of work satisfaction due to several factors, such as the job desk that } \\
\text { matches each individual's abilities, feedback, and a fair payment system. }\end{array}$ \\
\hline
\end{tabular}

\section{Introduction}

Within the village administration, the need to carry out the internal and external social functions influences the apparatus's welfare and sustainability. Therefore, in the competition between villages, an institution is required to possess superior human resources. In particular, the village head and apparatus must embed specific characteristics, such as being productive, innovative, creative, enthusiastic, and loyal.

An individual's activities in work are driven by motivation and work satisfaction. Work motivation is a simple yet complex aspect since it determines the extent of an individual's work performance. Work satisfaction is an essential element of the improvement of the work performance of organization members (Robbins, 2001).

Meanwhile, work satisfaction refers to a person's feelings towards one's job that is reflected from the positive attitude in the work environment due to the harmony between the guidelines system and the implementation of the duties of each member. Such an aspect, if implemented optimally, can contribute to the quality of community development.

The village head plays a significant role in managing, directing, and supervising the work environment in the village administrative office and the Mokupo village community. The aspect of work satisfaction is identified from these factors: 1) employees prefer jobs that allow them to use their skills and abilities and offer a variety of boundaries, freedoms, and feedback on the extent of their performance; 2) employees want a payment system and policies that they perceive as fair, unambiguous, and in line with their expectations. A fair payment based on job demands, individual skill levels, and communication standards will increase work satisfaction; 3) employees always care about a good work environment for personal comfort and ease of access in accomplishing their tasks more than just awards in the form of money; 4) employees also regard that work also fills the need for social interaction. Friendly and supportive co-workers, as well as the match between the employees' personalities, can contribute to increased work satisfaction.

Human resources play an important role in an institution; in this regard, an educated and competent village apparatus is needed to support government administrational affairs and village development. The government of Mokupo village requires the

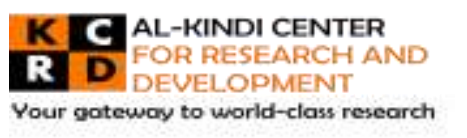

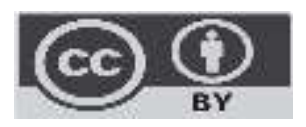

Published by Al-Kindi Center for Research and Development. Copyright (c) the author(s). This open access article is distributed under a Creative Commons Attribution (CC-BY) 4.0 license 
optimum participation of all levels of society as actors of development as well as the government's role as protector, guide, and director. The community and the village government must assist and complement each other in a united outlook of village development to achieve the objectives of the village and so that Mokupo village develops into a large, advanced, and independent village.

Based on the rationale, the study intends to elaborate on aspects related to the role of the village head's leadership in increasing the village apparatus' work satisfaction in Mokupo village, Karamat district, Buol regency.

\section{Literature Review}

\subsection{Leadership Concept}

An institution can achieve its organizational goals by the presence of good leadership. Leadership, in turn, is also influenced by several factors. The factors involve the employees in an organizational position; they occur in a specific situation and influence each other (Winardi, 2000). In a study conducted by Posner and Kouzes (2017), it was found that there are five relevant exemplary leadership practices to the development of leadership over the years.

Demonstrating: In a professional context, someone is more likely to be appreciated by the environment due to one's behavior more than one's title. An exemplary leader should be aware that one must practice good conduct and act as a role model to achieve a good performance standard.

Inspiring a collective vision: A good leader inspires a collective vision and encourages one's subordinates to accept and achieve the collective vision by creating bonds with them. People must believe that the leader understands their needs and cares about their desires.

Challenging the process: Leaders are pioneers that are willing to step into the unknown. They seek opportunities to innovate, grow, and improve.

Enabling others to take action: An exemplary leader enables others to act while fostering collaboration and building trust between oneself and one's subordinates. Teamwork involves all parties who have an obligation to make the project successful. A leader must have the ability to enable others to take action.

Cheering up: A leader encourages and cheers up one's subordinates to keep developing. It is seen as genuine care to keep people moving forward.

According to Nawawi (1995:74), leadership is divided into five main functions:

Instructive Function: As a communicator, the leader functions to determine the what (the content of the order), the how (how to do the order), the when (time to start, implement and report the results), and the where (where to do the order) to make decisions effectively. These aspects function to provide instructions to the subordinates.

Consultative Function: A leader employs the consultative function as two-way communication and consults with the subordinates in making decisions that require the perspective of others.

Participative Function: In carrying out the participatory function, a leader involves one's subordinates in making and implementing decisions. Each member of an organization has the same opportunity to carry out the activities according to their respective positions.

Delegation Function: In this context, a leader delegates the authority to make or determine decisions to others. It is also regarded as the leader's trust towards the delegated people to accomplish the task responsible. This particular function is of importance since the progress of an organization is a shared responsibility, and a leader cannot bear this responsibility alone.

Control Function: The control function assumes that an effective leader must be able to regulate the activities of its members in a directed manner and effective coordination that enables the achievement of collective goals. A leader implements the control function by guiding, directing, coordinating, and supervising the subordinates.

A leader is defined as someone who uses one's authority and leadership to direct subordinates in completing their work effectively to achieve organizational goals. On the other hand, leadership is the way a leader influences the behaviour of subordinates to cooperate and work productively to achieve organizational goals (Hasibuan, 2000:167).

\subsection{Work Satisfaction}

A leader's ability to manage an institution greatly affects the way the institution runs and the work satisfaction of the employees. Work satisfaction is the emotional situation felt by an employee regarding one's positive/negative perspective on one's job. Such an aspect reflects one's feelings towards the job. The employee's positive outlook reflects work satisfaction on one's tasks and work environment (Handoko, 1996). 
Moreover, work satisfaction is a way to self-actualize oneself to achieve psychological maturity. The failure to achieve work satisfaction can make employees feel frustrated (Strauss and Sayles in Handoko, 1996). In this regard, an organization with high work satisfaction tends to perform effectively compared to that with low work satisfaction (Robbins, 2001).

Work satisfaction is the combination of an individual's cognitive and affective satisfaction. Affective satisfaction is obtained from all positive emotional assessments in work; this aspect focuses on the employees' mood during work. Positive feelings or positive moods indicate the achievement of work satisfaction in the individuals. In the meantime, cognitive work satisfaction is obtained from a logical and rational assessment of conditions, opportunities, and/or outcomes. Locke (in Luthans, 2006) elaborates a comprehensive definition of work satisfaction that involves cognitive, affective, and evaluative attitude, that work satisfaction is an emotional state that comes from one's work experience or perspective. By this definition, work satisfaction is a response that describes the feelings of individuals towards their work. Work satisfaction is the result of employees' perceptions of their performance in accomplishing essential tasks. In general, work satisfaction is the most important and frequently studied attitude. In line with that, work satisfaction can also be regarded as a pleasant or positive emotional feeling that results from one's work experience.

There are three main dimensions of work satisfaction: work satisfaction is the emotional response to a work situation, work satisfaction is the extent of work performance results, and work satisfaction represents the employee's behavior. Someone with a high level of work satisfaction shows a positive attitude towards the job, and vice versa (Robbins, 2001).

Work satisfaction is an output of the positive and comfortable attitude of an individual in a job. By understanding the outcomes, work satisfaction can be identified and improved. The following are five factors of work satisfaction, also referred to as Job Descriptive Index (JDI) (Luthans and Spector in Robins, 2006).

The job is the degree to which a job provides enjoyable tasks, learning opportunities, and taking on responsibility as primary causes of work satisfaction. According to Locke, the intrinsic characteristics that determine work satisfaction comprise diversity, difficulty, amount of work, responsibility, autonomy, control over work methods, plurality, and creativity.

The payroll/salary: research by Theriault (1976) shows that work satisfaction indicates the absolute amount of salary received, the degree to which the salary meets the workforce's expectations, and how the salary is given. Wages and salaries are recognized as significant factors in work satisfaction.

Opportunities or job promotions: employees have the opportunity to develop themselves and expand their work experience by opening up opportunities for promotion.

Work colleagues: an individual's need for social relations will be fulfilled by having employees' co-workers. The conflict between co-workers will affect the level of employee satisfaction with work.

Mas'ud (2004) identifies two components of work satisfaction: The first is intrinsic satisfaction that includes a wide variety of duties, opportunities for growth, opportunities to implement abilities and skills, autonomy, trust, challenging and meaningful work situation, and others. The second is extrinsic satisfaction that includes salary, supervision, job security, status, and prestige. Emilisa (2001) also proposes another concept regarding dimensions of work satisfaction by quoting Desantis and Durts (1996) work entitled "Comparing work satisfaction Among Public and Private Sector Employees." The dimensions are:

Monetary and non-monetary rewards: Financial rewards and promotion opportunities are variables that are significantly related to work satisfaction. In addition, fringe benefits, such as vacation time, are another mechanism to complement the salary

Job characteristics: the medium for employees to carry out their duties that are matched with their skills, job significance, autonomy, and feedback. By this, the employees will use their experiences to achieve work satisfaction.

Work-environment characteristics: the work environment that can increase work satisfaction includes office surroundings and atmosphere.

Personal characteristics: the researchers studied several attributes of a person's character such as sex, age, race, and education that are related to work satisfaction.

Harold E. Burt in As'ad (2003) states that the factors that increase employee's work satisfaction are as follows:

1. The factor of a relationship between work colleagues

a. Relationship between leader and subordinates

b. Physical and work condition

c. Social relationship between work colleagues

d. Suggestions from colleagues

e. Emotional response of work situation

2. Individual Factor 
a. Attitude towards job

b. Age

c. Sex

3. Extrinsic factors

a. Employee's family situation

b. Recreations

c. Training and education

Robbins (2001) states that there are several indicators that determine work satisfaction. These indicators are as follows:

Mentally challenging job: Employees prefer jobs that give them the opportunity to use their skills and abilities and offer a variety of boundaries, freedoms, and feedback on the extent of their performance.

Appropriate reward: Employees want a pay system and promotion policy that they perceive as fair, unambiguous, and in line with their expectations. When wages are seen as fair based on job demands, individual skill levels, and communication standards, satisfaction is likely to result.

Supportive work atmosphere: Employees care about a good work environment for personal comfort and ease of performance.

Supportive work colleagues: Employees want to get more than just money or other tangible achievements from work. For most employees, work also fills the need for social interaction. In this case, friendly and supportive coworkers lead to increased work satisfaction.

Match between personality and job desk: A high match between a person's personality will produce a more satisfied and optimal performance at work

\subsection{Work Satisfaction Consequence}

A human resource manager is very interested in understanding various dimensions of work satisfaction and anticipating various possible consequences, especially negative ones. Robbins (2001) reveals the impact of work satisfaction, if optimized, can increase productivity, reduce absenteeism, and suppress work turnover.

Work dissatisfaction can lead to 1) exit/resignation: dissatisfaction expressed through behavior directed at leaving the organization might include searching for a new position or submitting a resignation letter; 2) vocal expressions: dissatisfaction expressed through active and constructive efforts might include suggestions for improvement, resolution of problems with the leader, and employees' union activities; 3 ) loyalty: dissatisfaction is expressed by passively waiting for conditions to improve. This includes speaking up for the organization, dealing with outside criticism, and trusting the management board to implement the proper conduct; 4) neglect of devotion: dissatisfaction is expressed by allowing conditions to worsen. These include chronic absenteeism or late arrivals, reduced effort, and increased error rates. Luthans (2006) suggests that job satisfaction affects performance; employees with a high level of satisfaction will perform better, although the results might not be directly observable.

\section{Methodology}

This research employed a qualitative method that emphasizes field observation and non-statistical analysis. Qualitative research emphasizes the use of the researcher oneself as a tool. Thus, researchers must be accepted by respondents and their environment in order to be able to uncover hidden data through speech, body language, behavior, and expressions that are commonly practiced. The study involved primary data obtained from observations and interviews and secondary data in the form of documents and relevant information.

This research was conducted from October to November 2020 and took place at the Office of the Mokupo Village Head, Karamat District, Buol Regency. This location was chosen to facilitate access to the required data and factor of time efficiency.

The sample of this research involved all twenty village officials who work in the Office of the Mokupo Village Head, Karamat District, Buol Regency. An overall sampling was conducted because the number of officers in the agency amounted to 20 people. According to Arikunto (1994:104), overall sampling is applied if the total population is less than 100 people.

Moreover, this study employed several methods to collect data, i.e., (1) Interview, in which direct questions were asked to the respondents, (2) Documentation, in which the author traced historical data in the form of letters, images, and so on, and (3) Observation, in which the author obtained an overview of the object of research.

Further, the data were analyzed using qualitative descriptive analysis techniques that consisted of (1) Data reduction: a process of simplifying rough data from the results of field observation, (2) Data presentation: a narrative description accompanied by charts or tables to clarify the data, (3) Incorporation of formula $P=F / N \times 100$, where $P$ is the percentage, $F$ is the frequency or number, and $\mathrm{N}$ is the number of respondents, and (4) Formulation of conclusions and verification from the data that has been 
collected previously. In addition, the quantitative data from the interviews were presented according to the interview guide and serve as a complement to the arguments of the interviewees.

\section{Results and Discussion}

The data on the village head leadership are presented in the following tables:

\subsection{Provision of motivation/support}

The indicators of village head's leadership in motivating the village apparatus are as follows:

Table 1. Distribution of respondents' answers regarding the village head's support for optimal work performance

\begin{tabular}{|l|c|c|}
\hline Answer & Frequency & Percentage \\
\hline Always & 15 & 75 \\
Often & 4 & 20 \\
Rare & 1 & 5 \\
\hline Total & $\mathrm{N}=20$ & 100 \\
\hline
\end{tabular}

Source: Primary data, 2020

As indicated from the previous table, 15 respondents (75\%) stated the village head always motivates the village apparatus to perform optimally, four respondents (20\%) stated the village head often motivates the village apparatus. One respondent (5\%) said that it was very rare for the village head to motivate the village apparatus. The following is an excerpt of the interview with the Mokupo village head:

"I always motivate the village apparatus to work optimally in order to provide service to the community. In this regard, motivation and support to the apparatus are essential." (source: Interview on 20 November 2020).

From the observation and interview results, the village head always motivates his subordinates to generate optimum performance.

\subsection{Responsibility}

Table 2. Distribution of respondents' answers on the village head's responsibility

\begin{tabular}{|l|c|c|}
\hline Answer & Frequency & Percentage \\
\hline Very responsible & 15 & 75 \\
Responsible & 4 & 20 \\
Quite irresponsible & 1 & 5 \\
Not responsible & 0 & 0 \\
\hline \multicolumn{1}{|c|}{ Total } & $\mathrm{N}=20$ & 100 \\
\hline
\end{tabular}

Source: Primary data, 2020

The previous table indicates that 15 respondents (75\%) stated the village head is highly responsible for one's own conduct, four respondents (20\%) stated the village head is responsible for the village, and one respondent (5\%) said that the head village lacked responsibility on the decision taken. The following is an excerpt of the interview with the Mokupo village head:

"As a trusted person in this village, I do not want to disappoint the community. Therefore, I should listen to their ideas and opinions and be responsible for the decisions made. This way, all of the communities will feel appreciated." (Source: Interview, 20 November 2020)

From the results of observation and interview, it is indicated that the village head is highly responsible for the important decisions made.

\subsection{Leadership style}

Table 3. Distribution of respondents' answers regarding village head's leadership style

\begin{tabular}{|l|c|c|}
\hline Answer & Frequency & Percentage \\
\hline Democratic & 17 & 85 \\
Charismatic & 2 & 10 \\
Paternalistic & 1 & 5 \\
Laissez-faire & 0 & 0 \\
Autocratic & 0 & 0 \\
\hline
\end{tabular}




\begin{tabular}{|c|c|c|}
\hline Total & $\mathrm{N}=20$ & 100 \\
\hline
\end{tabular}

Source: Primary data, 2020

The above table shows that 17 respondents (85\%) stated that the leadership style applied by the village head was in the form of democratic leadership so as to create harmonious integration, encouraging work passion, two respondents (10\%) said the village head applied a charismatic leadership style, and one respondent (5\%) said the village head applied a paternalistic style. In this regard, it can be concluded that the Mokupo village head has his own way of leading and providing motivation to work for the apparatus and the community.

\subsection{Activeness in encouraging participation}

Table 4. Distribution of respondents' answers regarding the village head's eagerness to encourage the participation of all apparatus

\begin{tabular}{|c|c|c|}
\hline Answer & Frequency & Percentage \\
\hline Very active & 17 & 85 \\
\hline Attentive & 2 & 10 \\
\hline Less attentive & 1 & 5 \\
\hline Passive & 0 & 0 \\
\hline Total & $N=20$ & 100 \\
\hline
\end{tabular}

Source: Primary data, 2020

Table 7 illustrates that 17 respondents (85\%) stated that the leader was very active in encouraging participation, while two respondents (10\%) said the leader was attentive in encouraging participation, and one respondent (5\%) said the leader lacked attention in encouraging participation. Therefore, this study concludes that a village head must play an active role in encouraging participation.

\subsection{Active role in directing and guiding}

Table 5. Distribution of respondents' answers regarding the village head's eagerness to direct, guide, and encourage the apparatus and the community

\begin{tabular}{|l|c|c|}
\hline Answer & Frequency & Percentage \\
\hline Always & 16 & 80 \\
Often & 2 & 10 \\
Occasionally & 2 & 10 \\
Rarely & 0 & 0 \\
Never & 0 & 0 \\
\hline \multicolumn{1}{|c|}{ Total } & $\mathrm{N}=20$ & 100 \\
\hline
\end{tabular}

Source: Primary data (2020)

As shown in table 8,16 respondents (80\%) stated that the village head always directs, guides, and encourages his apparatus and the community in carrying out their duties, two respondents (10\%) opined the village head often directs, guides, and encourages the apparatus in carrying out their duties, and two respondents (10\%) said that the village head occasionally directs, guides, and encourages officials and the community in carrying out their duties. The results suggest that the village head, as the village head, directs, guides, and encourages the apparatus in carrying out their duties and contributing to the village development.

\subsection{Active role in managing, directing, and supervising the environment}

The respondents' answers on the aspect of the village head's active role in managing, directing, and supervising the environment are as follows:

Table 6. Respondents' opinion regarding the roles of village heads in managing, directing, and supervising the environment

\begin{tabular}{|l|c|c|}
\hline $\begin{array}{l}\text { Indicator of the } \\
\text { response }\end{array}$ & Frequency (F) & Percentage \\
\hline Strongly agree & 17 & 85 \\
Agree & 3 & 15 \\
Disagree & 0 & 0 \\
\hline
\end{tabular}




\begin{tabular}{|l|c|c|}
\hline Strongly disagree & 0 & 0 \\
\hline & $\mathrm{N}=20$ & 100 \\
\hline
\end{tabular}

Source: Primary Data of 2020

As based on the above table, the strongly agree response dominated the poll with 17 respondents (85\%), followed by the "agree" response (three respondents, 15\%). None of the respondents chose to disagree or strongly disagree. In other words, the respondents agree that managing, directing, and monitoring the environment of the village head office in Mokupo village and society is of paramount importance.

The present work also pinpoints the contribution of job satisfaction to work performance. Job satisfaction is the output of the perception of village apparatus regarding their contribution in working. Provided in the following sections are indicators that determine job satisfaction (Robbins; 2001).

\subsection{Challenging work}

Table 7. Distribution of the responses regarding challenging work

\begin{tabular}{|l|c|c|}
\hline Response & Frequency (F) & Percentage (\%) \\
\hline Prefer frequent challenging tasks & 15 & 75 \\
Prefer less-frequent challenging tasks & 4 & 20 \\
Prefer low frequency of challenging tasks & 1 & 5 \\
\hline \multicolumn{1}{|c|}{ Sum } & $\mathrm{N}=20$ & 100 \\
\hline
\end{tabular}

Source: Primary Data Research of 2020

The above table shows that 15 respondents (75\%) admitted that the village apparatus prefers works that allow them to utilize their skills and give them freedom and feedback on their performance. Only four respondents (20\%) claimed that the apparatuses prefer to get jobs that demand fewer skills or works; even one respondent argued that s/he wanted to handle such works with minimum complexity. Simply put, the majority of the village apparatuses opted to participate in tasks that require their creativity with feedback upon completing the tasks.

\subsection{Rewards}

Table 8. Distribution of responses regarding rewards

\begin{tabular}{|c|c|c|}
\hline Response & Frequency (F) & $\begin{array}{l}\text { Percentage } \\
\text { (\%) }\end{array}$ \\
\hline Prefer a just honorary system and policy & 15 & 75 \\
\hline Less-concerned about a just honorary system and policy & 4 & 20 \\
\hline Lack of concern about a just honorary system and policy & 1 & 5 \\
\hline Sum & $N=20$ & 100 \\
\hline
\end{tabular}

Source: Primary Data Research of 2020

The above table reveals that 15 respondents (75\%) opt for just honorary policies that meet their expectations. Such a system is underpinned by the complexity of the work or task, employees' skills, and standard of communication; this principle results in job satisfaction. Four respondents (20\%) replied that only a few apparatuses are less concerned about the reward or honorary policies. Lastly, one respondent (5\%) stated that none of the apparatuses lacks concern about the reward or honorary policies.

\subsection{Supportive work atmosphere}

Table 9. Distribution of responses regarding supportive work atmosphere

\begin{tabular}{|l|c|c|}
\hline Response & $\begin{array}{c}\text { Frequency } \\
\text { (F) }\end{array}$ & Percentage (\%) \\
\hline Concerned about the work environment & 15 & 75 \\
Less-concerned about the work environment & 4 & 20 \\
Lack of concern about the work environment & 1 & 5 \\
\hline \multicolumn{1}{|c|}{ Sum } & $\mathrm{N}=20$ & 100 \\
\hline
\end{tabular}

Source: Primary Data Research of 2020

Based on the above table, 15 respondents (75\%) are concerned about a supportive workplace atmosphere contributing to their performance. However, four respondents (20\%) claim that four apparatuses are less concerned about their workplace 
environment, and one respondent stated that none of the apparatuses lacks concern about their work environment. In conclusion, most respondents prefer a supportive workplace atmosphere as it is central to maximizing their performance.

\subsection{Supportive work colleagues}

Table 10. Distribution of responses regarding supportive work colleagues

\begin{tabular}{|c|c|c|}
\hline Response & Frequency (F) & Percentage (\%) \\
\hline Concerned about the work colleagues & 15 & 75 \\
Less-concerned about work colleagues & 4 & 20 \\
Lack of concern about work colleagues & 1 & 5 \\
\hline Sum & $\mathrm{N}=20$ & 100 \\
\hline
\end{tabular}

Source: Primary Data Research of 2020

It is shown that 15 respondents (75\%) opine that many seek needs other than reward (i.e., money or appreciation for work performance), such as friendly work colleagues. Meanwhile, four respondents (20\%) clarify that not many apparatuses get rewards other than money or appreciation for their work achievement. As mentioned previously, one respondent (5\%) states that none of the apparatuses gets other rewards. Thereby, most employees in the research site still prefer to cooperate with friendly work colleagues.

\subsection{Compatibility of personality and job}

Table 11. Distribution of response regarding the compatibility of personality and job

\begin{tabular}{|c|c|c|}
\hline Response & $\begin{array}{c}\text { Frequency } \\
\text { (F) }\end{array}$ & Percentage (\%) \\
\hline There is a compatibility of the personality and job & 15 & 75 \\
There is no compatibility of the personality and job & 5 & 25 \\
\hline \multicolumn{1}{|c|}{ Sum } & $\mathrm{N}=20$ & 100 \\
\hline
\end{tabular}

Source: Primary Data Research of 2020

According to the above table, 15 respondents (75\%) believe that a job that fits well with employees' personality results in satisfaction in working. Five respondents, however, state that the compatibility of job and personality is less significant to job satisfaction.

In line with the above concept, the interview revealed that the respondents, such as village apparatuses and community leaders in Mokupo Village, claim that they are satisfied with the improved performance of the village head. This is evident from the satisfaction of the village apparatuses for every motivation from the village head. Furthermore, they opine that the village head has strived the best in ensuring that every decision has been made by taking into account the responsibility of the village head. Managing, directing, and monitoring the environment of the village head office in Mokupo Village and society is among the list of the duty of the village head. Moreover, the village head is also responsible for encouraging the village apparatuses to perform their best to contribute to better village development. The high satisfaction rate of the village apparatuses towards the performance of the village head is seen from the eagerness of the apparatuses to participate in tasks that require their creativities with the feedbacks upon the completion of the tasks. The rewarding system and honorary policies also contribute to the satisfaction rate of the performance of the village head. The majority of the apparatuses who prefer a supportive workplace atmosphere are also the reason for improved performance. Such a workplace atmosphere is also improved by supportive work colleagues and the compatibility of the job and each individual's personality in the research site.

\section{Conclusion}

The study intends to elaborate on aspects that are related to the role of the village head's leadership in increasing the village apparatus' work satisfaction in Mokupo village, Karamat district, Buol regency. The present work finds that the village head plays a significant role in motivating subordinates to perform effectively in conceptualizing better development in Mokupo Village. Also central to the improvement of the village is the participation of people. Job satisfaction of the apparatuses comes from their preference of job that requires them to utilize all of their skills. Furthermore, the apparatuses' motivation in the workplace is also driven by good reward management (the rewarding system is based on the complexity of the task, individual's skills, and communication standard). The majority of the apparatuses who prefer a supportive workplace atmosphere are also the reason for improved performance. Friendly work colleagues and the compatibility of the job and each individual's personality in the research site are also the keys to job satisfaction rates of the village apparatuses in the research site. This research is expected to be an input for the government in the research site to improve the village apparatus's work satisfaction and achieve a village's 
objectives. Since the present study is only limited to the area of Mokupo Village, thus further research is needed to be conducted in different areas with different geography and variables to be investigated.

Funding: This research received no external funding.

Conflicts of Interest: The authors declare no conflict of interest.

\section{References}

[1] As'ad, M. (2003). Psikologi industry [Industry Psychology]. Kementerian Pekerjaan Umum.

[2] DeSantis, Victor S. and Durts, Samantha L. (1996). Job satisfaction among public-and private-sector employees. The American Review of Public Administration, 26(3), 327-343.

[3] Dyer, L., \& Theriault, R. (1976). The determinants of pay satisfaction. Journal of Applied Psychology, 61(5), 596-604. https://doi.org/10.1037/0021-9010.61.5.596

[4] Emilisa, N. (2001). Hubungan antara job satisfaction dengan organizational commitment pada dana pension lembaga keuangan yang dikelola oleh perusahaan asuransi di Jakarta [The relationship between job satisfaction and organizational commitment on pension funds of financial institutions managed by insurance companies in Jakarta. Jurnal Media Riset Bisnis \& Manajemen, 1(3), 229 - 244.

[5] Handoko, T. H. (1996). Manajemen personalia dan sumber daya manusia [Personnel and human resource management]. BPFE.

[6] Hasibuan, M. S. P. (2000). Manajemen sumber daya manusia [Human Resource Management]. PT. Bumi Aksara.

[7] Luthans, F. (2006). Perilaku organisasi [Organizational behavior]. $10^{\text {th }}$ ed. PT. Andi.

[8] Mas'ud, F. (2004). Survai diagnosis organisasional [Organizational diagnostic survey]. Badan Penerbit Universitas Diponegoro.

[9] Nawawi, H. (1995). Kepemimpinan yang efektif [Effective Leadership]. Bumi Aksara.

[10] Posner, Barry and Kouzes, James. (2017). The leadership challenge: How to make extraordinary things happen in organizations. $6^{\text {th }}$ ed. Jossey-Bass.

[11] Robbins, S. (2001). Organizational behavior. 9th ed. Prentice Hall Inc.

[12] Usman, M. (1997). Keuangan dan perbankan Indonesia [Indonesian banking and finance]. Pinandita 